\title{
Biosynthesis of Low Molecular Weight (7S) and High Molecular Weight (19S) Immunoglobulin M
}

\author{
Alan Solomon and Carla L. McLaughin \\ From the University of Tennessee Memorial Research Center and Hospital, \\ Knoxville, Tennessee 37920
}

\begin{abstract}
A в S T R A C T The class of immunoglobulin M ( $\operatorname{IgM}$ ) characterized by high molecular weight proteins with a sedimentation coefficient of $19 \mathrm{~S}$, includes a smaller molecular form with an $50, w$ of approximately 7 . The synthetic origin of the 7S IgM was investigated by biosynthetic studies on bone marrow cells from three patients with macroglobulinemia whose sera contained 7S IgM and 19S IgM. Labeled 7S IgM and 19S IgM were identified in extracellular culture fluids by radioimmunochemical techniques. The separation of the two molecular forms of IgM by density-gradient ultracentrifugation of the culture fluids before radioimmunochemical analyses permitted the identification of both the labeled 7S IgM and 19S IgM. One patient's serum contained two separate and distinct 19S IgM proteins as well as 7S IgM. The use of specific isolated carrier IgM proteins permitted the radioimmunochemical detection of labeled 7S IgM and both 19S IgM proteins. The introduction of cycloheximide into a culture system effects the cessation of protein synthesis. The analyses of culture fluids harvested at timed intervals after the addition of cycloheximide revealed not only the stability of $19 \mathrm{~S} \operatorname{IgM}$ to intracellular proteolysis, but also provided evidence for a possible precursor-product relationship between the 7S $\mathrm{IgM}$ and the 19S IgM. The demonstration that the labeled 7S IgM is neither an in vitro breakdown product of $19 \mathrm{~S} \mathrm{IgM}$ nor a resultant of $19 \mathrm{~S} \mathrm{IgM}$ intracellular catabolism substantiated the synthetic origin of $7 \mathrm{~S} \operatorname{IgM}$ in human sera.
\end{abstract}

\section{INTRODUCTION}

Immunoglobulin $\mathrm{M}$ ( $\operatorname{Ig} M)$ has been characterized by proteins with a sedimentation coefficient of $19 \mathrm{~S}$ (summarized in reference 2 ). Whereas this class of immuno-

This work was presented in part at the Tenth Annual Meeting of the American Society of Hematology, Toronto, Cariada, 5 December 1967 (1).

Received for publication 27 March 1969 and in revised form 16 September 1969. globulins has been distinguished by high molecular weight proteins, a smaller molecular form of IgM has been recognized in normal newborn and adult sera and in the serum of patients with lupus erythematosus, type I dysgammaglobulinemia, ataxia telangiectasia, leukemia, lymphoproliferative and infectious diseases, and Waldenström's macroglobulinemia (3-11). This low molecular weight IgM has a sedimentation coefficient of approximately $7 \mathrm{~S}$ and has been evident most often in the serum of patients with $19 \mathrm{~S}$ macroglobulinemia. The 7S IgM has been detected in the majority of such patients and has comprised up to $45 \%$ of the total IgM present (7, 10,11 ).

Anti-IgM antisera have not had the capacity to distinguish between 7S IgM and 19S IgM. ${ }^{1}$ The lack of specific anti-7S IgM antiserum has prevented the direct detection of 7S IgM; however, the combination of immunochemical techniques with methods ${ }^{2}$ which separate the two molecular forms of $\operatorname{IgM}$ has made feasible the detection of $7 \mathrm{~S} \mathrm{IgM}$ in human sera.

The demonstration of the polymeric structure of $19 \mathrm{~S}$ $\operatorname{Ig} \mathrm{M}$ by dissociation with mercaptans (13) led to the establishment of the pentameric structure (14) consisting of subunits linked via a single disulfide bond (15) between a cysteinyl residue at or penultimate to the carboxyl-terminus $(16,17)$ of the $\mu$ heavy chains of each subunit. An exact relationship has not been established between the naturally occurring $7 \mathrm{~S} \operatorname{IgM}$ and the monomeric subunit produced by reduction (18) or by reduc-

\footnotetext{
${ }^{1}$ Recently, a report has been made of an anti-19S $\operatorname{IgM}$ antiserum which can distinguish between $19 \mathrm{~S} \mathrm{IgM} \mathrm{and} \mathrm{7S}$ IgM (12). An anti-19S IgM antiserum with a similar capacity has been obtained in our laboratory and is being used in immunoelectrophoretic and immunodiffusion analyses to detect 7S IgM directly in sera.

${ }^{2}$ Density-gradient ultracentrifugation and gel filtration provide a means of separating 7S IgM from 19S IgM (311). The molecular sieving effect of high concentrations of acrylamide, agarose, and gelatin in immunodiffusion analyses permits identification and quantitation of $7 \mathrm{~S} \mathrm{IgM} \mathrm{in} \mathrm{whole}$ sera $(7,10,11)$
} 
tion and alkylation of the 19S IgM pentamer. Results of in vitro and in vivo studies have indicated that the 7S IgM is neither a breakdown nor a catabolic product of 19S IgM. The 7S IgM has not been detected after repeated freezing and thawing or prolonged incubation of isolated 19S IgM preparations, nor after similar treatment of sera containing only the $19 \mathrm{~S}$ form of $\operatorname{IgM}(7,8$, $10,11)$. The $7 \mathrm{~S} \operatorname{IgM}$ has been detected in fresh sera obtained and analyzed under aseptic conditions and in sera analyzed in the presence of sulfhydryl-blocking agents (10). The intravenous injection of homologous radioiodinated 19S IgM into a patient whose serum contained both molecular forms of IgM did not result in formation of labeled protein corresponding to $7 \mathrm{~S} \operatorname{IgM}$ (6). Further, the presence of $7 \mathrm{~S} \mathrm{IgM} \mathrm{has} \mathrm{no} \mathrm{dependence}$ on the concentration of $19 \mathrm{~S} \operatorname{IgM}$ in the serum $(7,10$, 11). A relationship between the serum concentration of the 7S IgM and the 19S IgM has not been apparent; in one patient's serum the $7 \mathrm{~S}$ IgM represented almost the total concentration of IgM molecules (6).

The refutation of the catabolic origin of $7 \mathrm{~S} \operatorname{IgM}$ stimulated our investigations designed to affirm the synthetic origin of 7S IgM. Biosynthetic studies were performed on bone marrow cells from three patients whose sera contained 7S IgM and $19 \mathrm{~S} \operatorname{IgM}$. The radioimmunochemical detection of labeled $7 \mathrm{~S} \operatorname{IgM}$ and $19 \mathrm{~S} \operatorname{IgM}$ in the culture fluids and the demonstration of the stability of $19 \mathrm{~S} \operatorname{IgM}$ to extracellular or intracellular proteolysis provided evidence for a synthetic origin of $7 \mathrm{~S} \operatorname{IgM}$ in human sera.

\section{METHODS}

\section{Analytic procedures}

Cellulose acetate electrophoresis was performed on a Microzone apparatus (Beckman Instruments, Inc., Fullerton, Calif.). Optimum resolution of the IgM proteins was obtained by electrophoresis for $40 \mathrm{~min}$ in 0.05 ionic strength barbital buffer, $\mathrm{pH}$ 8.6. The membranes were stained with Ponceau S, and the distribution of protein was determined by densitometry with a Beckman Analytrol. The protein concentration in whole serum was determined by refractometry and that of isolated protein preparations by a modification of the Folin-Ciocalteu method (19). Analytic ultracentrifugation was performed in a Spinco model $E$ centrifuge using an An-D rotor and double-sector cells at 52,640 or at 56,100 $\mathrm{rpm}$. Schlieren patterns were analyzed with the aid of a microcomparator (Gaertner Scientific Corp., Chicago, Ill.) and the sedimentation coefficient, $s_{\text {obs }}$, was corrected to $s_{20, w}(20)$. The $s_{20, w}$ was determined on at least three different concentrations of each sample in $0.15 \mathrm{M} \mathrm{NaCl}$. Density-gradient ultracentrifugation was performed in a Spinco model $\mathrm{L}$ centrifuge with a SW 39 swinging bucket rotor at $33,000 \mathrm{rpm}$ for $15 \mathrm{hr}$ at $4^{\circ} \mathrm{C}$ (2). $10-40 \%$ sucrose gradients were prepared in $0.15 \mathrm{M} \mathrm{NaCl}$; consecutive fractions were obtained either by puncturing the bottom of the tube and collecting the effluent drops, or by means of an automatic gradient fractionator; the protein concentration was monitored at $254 \mathrm{~m} \mu$ (Instrument Specialities Co., Inc., Lincoln, Neb.).

\section{Preparative procedures}

Isolation of immunoglobulin components was achieved by preparative block electrophoresis (21). Proteins were further purified by gel filtration (3) through Bio-Gel P-200 polyacrylamide (Bio-Rad Laboratories, Richmond, Calif.) $2.5 \times 100 \mathrm{~cm}$ columns. The eluting buffer at $\mathrm{pH} 7.6$ was composed of $0.15 \mathrm{M} \mathrm{NaCl}, 0.05 \mathrm{M}$ Tris- $\mathrm{HCl}, 0.001 \mathrm{M}$ ethylenediaminetetraacetate (EDTA), and $0.003 \mathrm{M}$ sodium azide.

\section{Immunochemical procedures}

A $2 \%$ agar medium, prepared in barbital buffer, $\mathrm{pH} 8.6$, 0.075 ionic strength and containing $0.01 \mathrm{M}$ sodium azide, was employed in microimmunoelectrophoretic (22) and immunodiffusion analyses (23). Antiserum to whole human serum was obtained from Hyland Laboratories, Los Angeles, Calif. Antisera to $19 \mathrm{~S}$ IgM and to light chains of type $\mathrm{K}$ and type $\mathrm{L}$ were prepared in rabbits by immunization with Waldenström-type 19S M-macroglobulins and with $\kappa$ - and $\lambda$-type Bence Jones proteins. The antisera were rendered specific for $\mu$ heavy chain determinants or for $\kappa$-type or $\lambda$-type light chain determinants by appropriate absorption (24). The anti-IgM antisera did not distinguish between the 7S IgM and the 19S IgM; in order to quantitate 7S $\operatorname{IgM}$ and $19 \mathrm{~S} \operatorname{IgM}$ in whole serum it was necessary to first isolate the two molecular forms. Separation of the 7S IgM and the 19S IgM was achieved by density-gradient centrifugation of the serum. Two pools were prepared from the gradient fractions; one contained rapidly sedimenting (19S) IgM protein and the other contained slowly sedimenting (7S) IgM protein. The amount of IgM in each pool was determined by electroimmunodiffusion (25). Serial dilutions of an isolated $19 \mathrm{~S} \operatorname{IgM}$, served as the reference standard for the $19 \mathrm{~S} \mathrm{IgM}$. Serial dilutions of the monomeric (7S) subunit prepared by reduction and alkylation (26) of the 19S IgM served as the reference standard for the 7S IgM. Similar quantitative data were obtained with the same anti-IgM antiserum when using isolated naturally occurring 7S IgM as the reference standard.

\section{Biosynthetic studies}

Cultures were established with bone marrow cells obtained from three patients with macroglobulinemia (F. C., W. F., and R. B.). Bone marrow F. C. was extensively infiltrated by plasma cells and to a lesser extent by lymphocytes and lymphocytoid plasma cells. The predominant cells present in bone marrow W. F. and R. B. were lymphocytes and lymphocytoid plasma cells. Approximately $1 \mathrm{ml}$ of bone marrow was aspirated with a heparinized syringe and suspended in $10 \mathrm{ml}$ of sterile Hank's solution. The marrow particles were collected by centrifugation at $230 \mathrm{~g}$ for $10 \mathrm{~min}$ at $4^{\circ} \mathrm{C}$, and were then washed three times by suspending the particles in Hank's solution, centrifuging, and decanting the supernatant. A final suspension was made in $8 \mathrm{ml}$ of an isoleucine-lysine deficient growth medium ${ }^{3}$ containing $5 \mathrm{mg} /$ $\mathrm{ml}$ of $3 \times$ crystallized ovalbumin (Nutritional Biochemicals Corporation, Cleveland, Ohio). Radioactive isoleucine and lysine were added to yield $1 \mu \mathrm{Ci} / \mathrm{ml}$ of L-isoleucine $-{ }^{14} \mathrm{C}$ ( $\mathrm{SA}$ $198 \mathrm{mCi} / \mathrm{mmole}$, Schwartz Bio Research Inc., Orangeburg, N. Y.) and $1 \mu \mathrm{Ci} / \mathrm{ml}$ of L-lysine $-{ }^{11} \mathrm{C}$ (SA $234 \mathrm{mCi} / \mathrm{mmole}$, New England Nuclear Corp., Boston, Mass.) prior to transferring of $1 \mathrm{ml}$ aliquots to sterile $16 \times 125 \mathrm{~mm}$ glass screw-

${ }^{8}$ NIH. Medium 320, kindly supplied by Dr. Richard Asofsky, National Institutes of Health, Bethesda, Md. 
top tubes. The tubes were placed in a roller drum at $37^{\circ} \mathrm{C}$ and duplicate tubes removed at selected time intervals for processing. The culture fluid was harvested by centrifugation at $230 \mathrm{~g}$ for $10 \mathrm{~min}$ at $4^{\circ} \mathrm{C}$ and then dialyzed extensively against $0.15 \mathrm{M} \mathrm{NaCl}$ at $4^{\circ} \mathrm{C}$ to remove unincorporated ${ }^{14} \mathrm{C}$ - labeled amino acids. Radioimmunoelectrophoresis was performed as described by Hochwald, Thorbecke, and Asofsky (27). Samples in Bray's solution (28) were assayed for radioactivity in a Packard Tri-Carb liquid scintillation spectrometer.
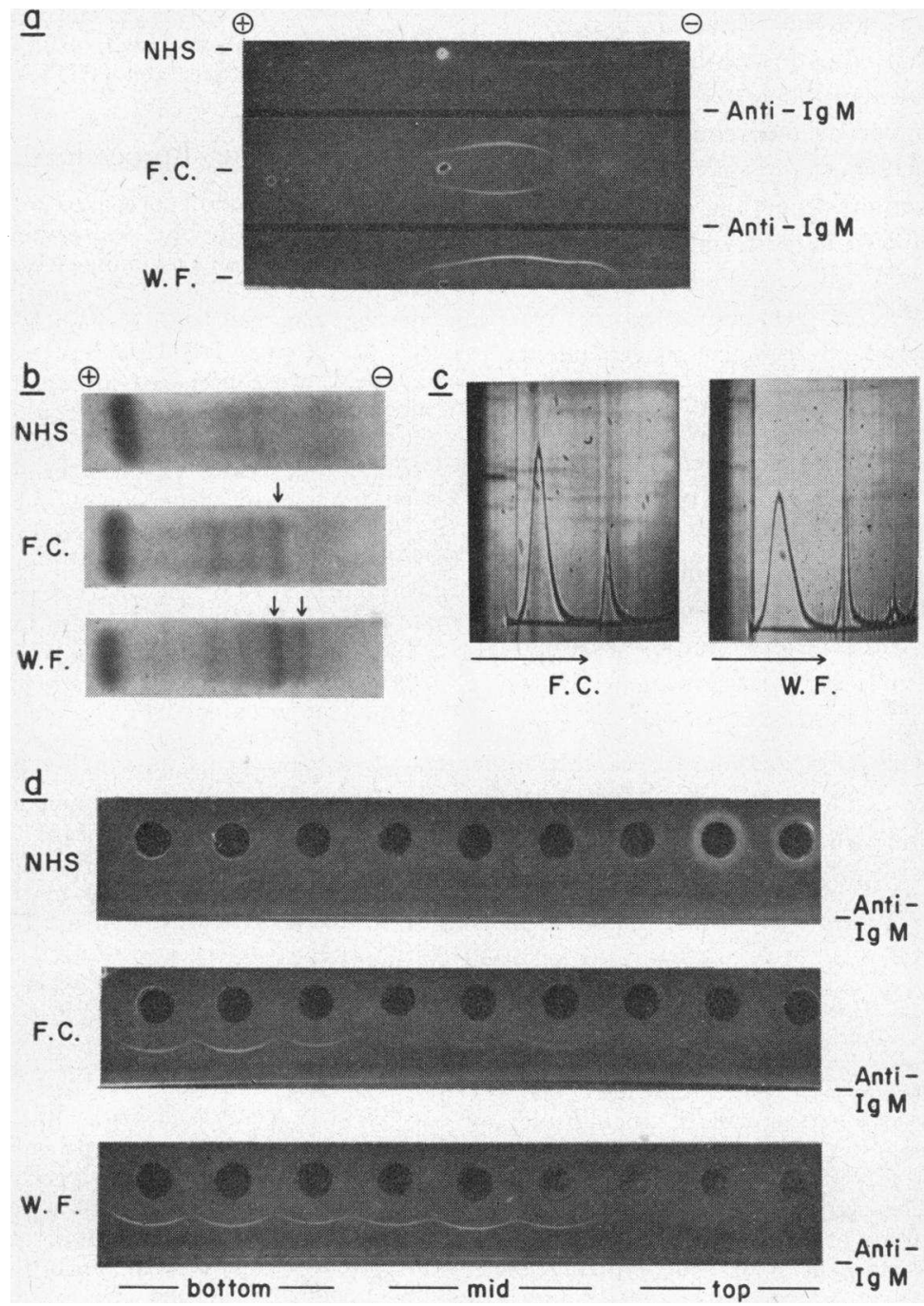

Figure 1 Immunochemical and physicochemical analyses of serum F. C. and serum W. F. (a) Immunoelectrophoresis. The antiserum troughs contained specific anti-IgM antiserum (NHS: normal human serum). (b) Cellulose acetate electrophoresis. The anomalous component in serum F. C. and the two anomalous components in serum W. F. are indicated by arrows. (c) Analytic ultracentrifugation. The sera were diluted fourfold with $0.15 \mathrm{M} \mathrm{NaCl}$ and photographs were taken $32 \mathrm{~min}$ after reaching full speed of $52,640 \mathrm{rpm}$. The direction of sedimentation, to the right, is indicated by the arrow. (d) Analyses of density gradient fractions by immunodiffusion. $0.3 \mathrm{ml}$ of a threefold dilution of serum was layered on a $10-40 \%$ sucrose density-gradient and centrifuged (see Methods). The antigen wells were filled with alternate consecutive fractions from the top to the bottom of the gradient. The antiserum troughs contained specific anti-IgM antiserum. The IgM in normal human serum (NHS) was confined in fractions from the bottom of the gradient, whereas in sera F. C. and W. F., fractions from the bottom and midportion of the gradient contained $\operatorname{IgM}, 19 \mathrm{~S}$ and $7 \mathrm{~S}$, respectively. 


\section{Patient data}

Patient $F$. C. was a $67 \mathrm{yr}$ old male in whom a diagnosis of Waldenström's macroglobulinemia was made in 1961. Biweekly plasmaphereses were required to control the serum hyperviscosity and thereby maintain a relatively asymptomatic state. The patient also received chemotherapy: chlorambucil was administered until 1965, and then treatment with cyclophosphamide was instituted. In March, 1967, the chemotherapy was discontinued and no further plasmaphereses were required. At the time of this study (June, 1967) the serum IgM represented approximately $14 \%$ of the total serum protein concentration. In addition to $19 \mathrm{~S}$ IgM, slowly sedimenting protein with IgM antigenic determinants (7S IgM) was detected by immunochemical analysis of density-gradient fractions of the serum." Both the 19S IgM and $7 \mathrm{~S}$ IgM possessed type $\mathrm{K}$ light chains.

Patient $W$. F. was an 82 yr old male in whom pancytopenia and macroglobulinemia were discovered in 1968. Electrophoretic analyses on the serum and ultracentrifugal studies on two anomalous components isolated from the serum revealed the presence of two $19 \mathrm{~S}$ IgM proteins. The concentration of the more cathodally migrating $19 \mathrm{~S}$ IgM was $1.2 \mathrm{~g} / 100 \mathrm{ml}$, and the concentration of the less cathodally migrating 19S IgM was $3.2 \mathrm{~g} / 100 \mathrm{ml}$. Not only was $19 \mathrm{~S}$ IgM detected by immunochemical analysis of density-gradient fractions of this patient's serum, but also 7S IgM was detected. Both 19S IgM proteins and the 7S IgM had type $\mathrm{K}$ light chains. The patient had received no drug therapy before the time of the initial study in April, 1968. 4 months after treatment with cyclophosphamide and prednisone was initiated, the patient's blood count was within normal values although the marrow lymphocytic infiltration was still present.

Patient $R$. B. was a $45 \mathrm{yr}$ old female in whom a diagnosis of Waldenström's macroglobulinemia was made in 1965. Neither treatment with chlorambucil nor with cyclophosphamide and prednisone was effective in controlling the hyperviscosity state. Weekly or biweekly plasmaphereses, initiated in 1967, have maintained the patient relatively asymptomatic. At the time of this study (May, 1969) the anomalous serum protein component was isolated and identified as a 19S IgM with type $\mathrm{K}$ light chains. Although no slowly sedimenting IgM was detected by immunodiffusion analysis of fractions obtained by density-gradient ultracentrifugation of $0.1 \mathrm{ml}$ of serum, 7S IgM was detected in the fractions from the mid $(7 \mathrm{~S})$ portion of the gradient by the more sensitive electroimmunodiffusion technique (25). Immunochemical comparison of the pooled and concentrated 7S gradient fractions and the pooled 19S gradient fractions with an antiserum which could distinguish between 7S IgM and $19 \mathrm{~S} \mathrm{IgM} \mathrm{(see} \mathrm{footnotes} 1$ and 5) confirmed the presence of the $7 \mathrm{~S} \operatorname{IgM}$ in the serum of patient $R$. B.

\footnotetext{
- The 7S IgM protein was detected in a serum specimen obtained in 1961, before therapy, as well as in sera obtained in 1964 and 1965 (all specimens had been maintained at $-30^{\circ} \mathrm{C}$ ).

'The IgM protein detected in the midportion of the gradient was not the result of "tailing" of the 19S IgM (10). Proof that the IgM protein detected in the midportion of the gradient is distinct from the $19 \mathrm{~S} \mathrm{IgM} \mathrm{was} \mathrm{obtained} \mathrm{by}$ immunochemical analyses in which the anti-IgM antiserum with specificity for the $19 \mathrm{~S} \mathrm{IgM} \mathrm{(see} \mathrm{footnote} \mathrm{1)} \mathrm{was} \mathrm{used.}$ The 7S IgM isolated by density-gradient ultracentrifugation was again localized to the $7 \mathrm{~S}$ region of the gradient after repeat analysis.
}

The immunochemical and physicochemical detection and identification of $19 \mathrm{~S} \mathrm{IgM}$ and $7 \mathrm{~S} \operatorname{IgM}$ in the serum of patients F. C. and W. F. are illustrated in Fig. 1.5 The serum concentration of the 7S IgM and 19S IgM for all three patients at the time of each biosynthetic study are presented in Table I.

TABLE I

Serum Concentrations of $7 S$ IgM and $19 S \operatorname{Ig} M^{*}$

\begin{tabular}{lccc}
\hline \multicolumn{1}{c}{ Patient } & 7S IgM & 19S IgM & 7S IgM \\
\hline & $m g / m l$ & $m g / m l$ & $\begin{array}{c}\text { \% of } \\
\text { total IgM }\end{array}$ \\
F. C. & 0.7 & 10.7 & 6.1 \\
R. B. & 0.2 & 36.0 & 0.5 \\
W. F. & & &. \\
April, 1968 & 1.5 & 48.0 & 3.0 \\
April, 1969 & 2.2 & 30.0 & 6.8 \\
May, 1969 & 1.3 & 23.0 & 5.3 \\
\hline
\end{tabular}

* Serum concentrations at time of biosynthetic study.

\section{RESULTS}

Newly synthesized IgM, i.e. labeled protein, was identified in culture fluids by radioimmunochemical techniques. In the immunochemical analyses anti-IgM, anti-light chain, and anti-whole human serum antisera were used; the patient's serum provided the source of carrier proteins. In the immunoelectrophoretic analysis of culture fluid F. C., harvested after $16 \mathrm{hr}$ of incubation, only a single intense IgM precipitin arc was obtained with specific anti-IgM antiserum; direct comparison of the radioautogram with the immunoelectrophoretic pattern revealed exact correspondence between the labeled arc and the IgM precipitin arc. The synthesized IgM contained only type $\mathrm{K}$ light chain determinants as indicated by radioimmunoelectrophoretic analyses with the antilight chain antisera. No other labeled serum protein components were detected by radioimmunoelectrophoresis in which anti-whole human serum antiserum was used.

The molecular distribution of the labeled protein in the culture fluid was determined by density-gradient ultracentrifugation. In order that a profile of the serum protein distribution be available for comparison with the profile of the distribution of radioactivity, the patient's serum was added to the culture fluid before centrifugation. The analysis of culture fluid F. C. (Fig. $2 a$ ) revealed three separate peaks of radioacivity: the major peak of radioactivity, located at the bottom of the gradient, was associated with rapidly sedimenting serum proteins; the middle and upper peaks of radioactivity, located in the mid and top regions of the gradient, were associated with intermediate and slowly sedimenting serum proteins, respectively. The bottom and the middle peaks of radioactivity corresponded to the location of 19S IgM and 7S IgM, respectively (see Fig. $1 \mathrm{~d}$ ). The 
presence of labeled IgM protein in both the bottom and middle peaks of radioactivity was demonstrated by radioimmunodiffusion analyses of the gradient fractions (Fig. $2 b$ ). No labeled protein possessing $\mu$ or $\gamma$ heavy chains or type $\mathrm{K}$ or $\mathrm{L}$ light chains was detected in the upper (slowest sedimenting) peak. The presence of labeled 19S IgM in the bottom peak and labeled 7S IgM in the middle peak was confirmed by radioimmunoelectrophoretic analyses of the central fraction of both the bottom and the mid peaks.

As evidenced by radioimmunoelectrophoretic analyses, all four culture fluids W. F. harvested after 3, 6, 10, and $22 \mathrm{hr}$ of incubation contained both of the 19S IgM proteins and the 7S IgM protein. The configuration of the arc on each radioautogram was identical with the configuration of the IgM precipitin arc obtained with specific anti-IgM antiserum. The double deflection of the labeled arc, indicating the presence of both 19S IgM components, was quite apparent. Conclusive evidence for the presence in all four cultures of both 19S IgM proteins as well as the 7S IgM protein was obtained radioimmunoelectrophoretically by using specific IgM carrier proteins, i.e., the isolated $7 \mathrm{~S} \operatorname{IgM}$, the less cathodal 19S IgM, and the more cathodal 19S IgM (Fig. 3). A distinct difference in electrophoretic mobility of the three IgM proteins was obvious in the immunoelectrophoretic analysis, and the arcs of the developed radioautogram had exact correspondence with the respective IgM precipitin arcs. The $7 \mathrm{~S} \operatorname{IgM}$ and the two 19S IgM proteins possessed only type $\mathrm{K}$ light

a

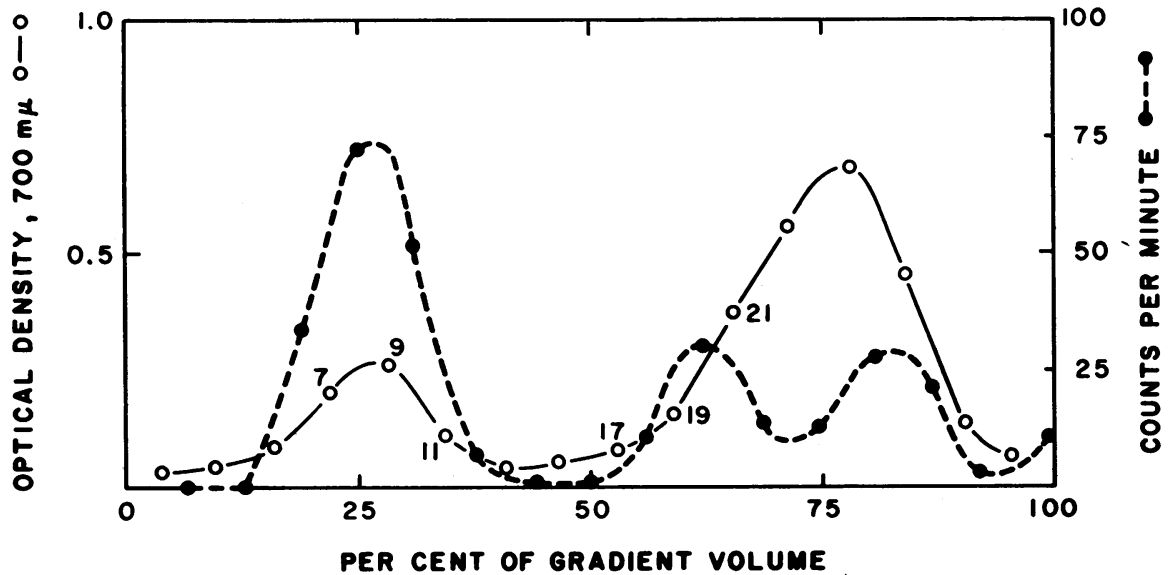

$\underline{b}$
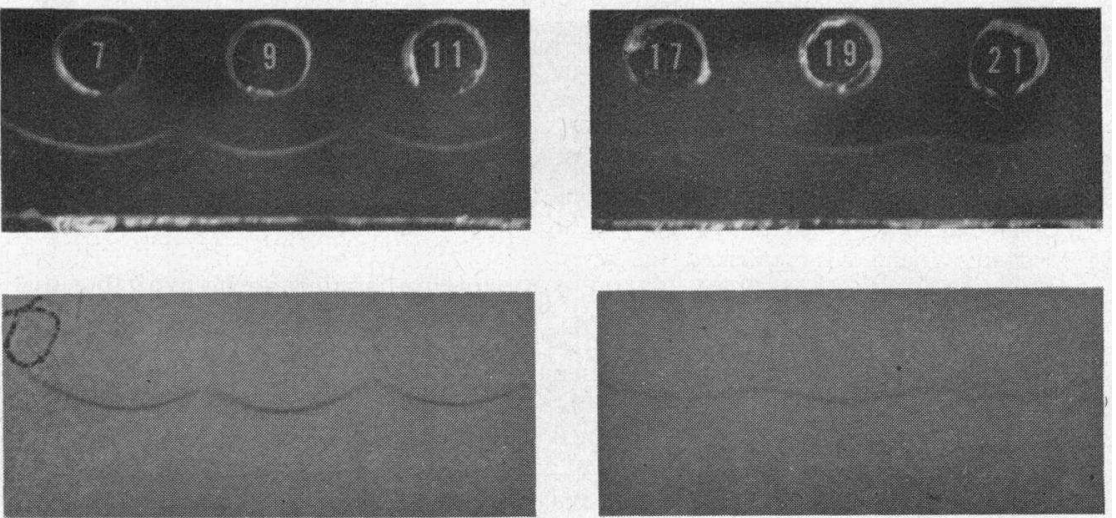

FIGURE 2 The molecular distribution of labeled protein in culture fluid F. C. $50 \mu$ of culture fluid and $0.2 \mathrm{ml}$ of a $1: 3$ dilution of serum F. C. were layered on a $10-40 \%$ sucrose density gradient and centrifuged (see Methods). (a) The profiles of protein content $(\mathrm{O}-\mathrm{O})$ and radioactivity $(\bullet---\bullet)$ in the gradient fractions were compared. (b) The indicated gradient fractions were analyzed by radioimmunodiffusion in which specific anti-IgM antiserum was used. The radioautogram was developed after 36 days exposure. 


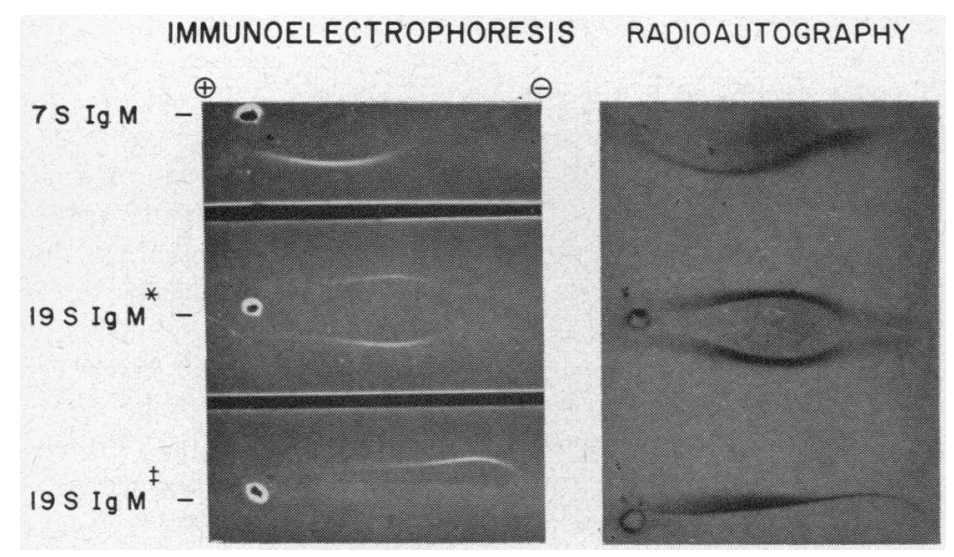

FIgURE 3 Identification of $7 \mathrm{~S} \operatorname{IgM}$ and the two 19S IgM proteins in culture fluid W. F. (Left) Immunoelectrophoresis. All three antigen wells contained $10 \mathrm{hr}$ culture fluid W. F. plus the designated specific IgM carrier protein (19S IgM*: less cathodal 19S IgM; 19S IgM‡: more cathodal $19 \mathrm{~S}$ IgM). Both antiserum troughs contained specific anti-IgM antiserum. (Right) Radioautography. The radioautogram was developed after 37 days exposure.

chain antigenic determinants as evidenced by the radioimmunoelectrophoretic analyses in which anti-light chain antisera were used.

The molecular distribution of labeled protein in the 3 , 6,10 , and $22 \mathrm{hr}$ culture fluids W. F. was determined by density-gradient ultracentrifugation (Fig. 4). Slight differences in the protein profiles were due to minor variations in each density gradient. Labeled IgM was detected radioimmunochemically in fractions located at the bottom and midportion in each of the four gradients. In agreement with the results obtained with culture fluid F. C., no labeled protein could be detected in the upper (slowest sedimenting) peak of radioactivity radioimmunochemically with anti-normal human serum antiserum. A comparison of the distribution of radioactivity within each of the four gradients revealed a shift in the relative distribution of radioactivity with a marked decrease in radioactivity associated with slowly sedimenting material. The radioactivity associated with the $19 \mathrm{~S}$ peak and the 7S peak was determined by measuring the area under the respective peaks. A comparison of the percentage of $19 \mathrm{~S}+7 \mathrm{~S}$ radioactivity associated with the $19 \mathrm{~S}$ peak in each of the four cultures showed a progressive increase in $19 \mathrm{~S}$ radioactivity $(23-68 \%)$ with a concomitant decrease in $7 \mathrm{~S}$ radioactivity. Radioimmunoelectrophoretic analyses of fractions localized to the $19 \mathrm{~S}$ and $7 \mathrm{~S}$ peaks were performed with anti-IgM and anti-normal human serum antisera; the only labeled protein detected in each peak was IgM.

Density-gradient analyses provided information concerning the distribution of radioactivity between only the 19S IgM and 7S IgM. The distribution of radioactivity between the two 19S IgM proteins in culture fluids
W. F. was determined by separating the two labeled 19S IgM proteins in the $10 \mathrm{hr}$ and $22 \mathrm{hr}$ culture fluids by electrophoresis on cellulose acetate membranes (see Fig. $1 b$ ) which were sectioned and assayed for radioactivity. ${ }^{6}$ In both cultures the amount of radioactivity associated with each $19 \mathrm{~S} \operatorname{IgM}$ component indicated a ratio of approximately $4: 1$ between the less cathodal and more cathodal 19S IgM proteins.

After the initial biosynthetic study, patient W. F. was examined at periodic intervals. The observation that the serum concentration of the $19 \mathrm{~S}$ IgM proteins had decreased to $30 \mathrm{mg} / \mathrm{ml}$ and the concentration of $7 \mathrm{~S} \operatorname{IgM}$ had increased to $2.2 \mathrm{mg} / \mathrm{ml}$ prompted a second biosynthetic study in April, 1969, and provided an opportunity to investigate further the stability of the labeled IgM proteins. The stability of the labeled $19 \mathrm{~S} \operatorname{IgM}$ and $7 \mathrm{~S}$ $\operatorname{IgM}$ in the 1968 cultures W. F. was evident from the density-gradient analyses of the culture fluids after each had been repeatedly frozen and thawed. A portion of the $10 \mathrm{hr}$ (1968) culture fluid W. F. was added to bone marrow cells W. F. (1969) in the culture medium containing no labeled amino acids and incubated for 22 $\mathrm{hr}$; an equal volume of the $10 \mathrm{hr}$ culture fluid was incubated for $22 \mathrm{hr}$ in $0.15 \mathrm{~m} \mathrm{NaCl}$. Both samples were ana-

\footnotetext{
- The distribution of radioactivity between the two $19 \mathrm{~S}$ IgM proteins W. F. was determined as follows: culture fluid $(35 \mu 1)$ was mixed with the patient's serum $(2 \mu 1)$ and applied four times to positions 2-7 on an 8 place membrane; for reference purpose, the serum was applied once to positions 1 and 8. After electrophoresis, the membrane was stained, cleared, and dried. Sections corresponding to the two $19 \mathrm{~S}$ $\mathrm{IgM}$ proteins were cut from the membrane, dissolved in scintillation fluid, and the radioactivity measured.
} 
lyzed by density-gradient centrifugation; the profiles of radioactivity were compared and found to be identical.

Bone marrow cells W. F. were incubated in the culture medium containing lysine- ${ }^{14} \mathrm{C}$ and isoleucine $-{ }^{14} \mathrm{C}$, and extracellular culture fluid was harvested at $6,22,26,30$, and $46 \mathrm{hr}$. Specific carrier proteins were used in the radioimmunoelectrophoretic demonstration of the presence of both labeled 19S IgM proteins and labeled 7S IgM protein. While the total concentration of 19S IgM proteins was less at the time of this study as compared with 19S IgM concentration at the time of the first study, the ratio of the less cathodal to the more cathodal

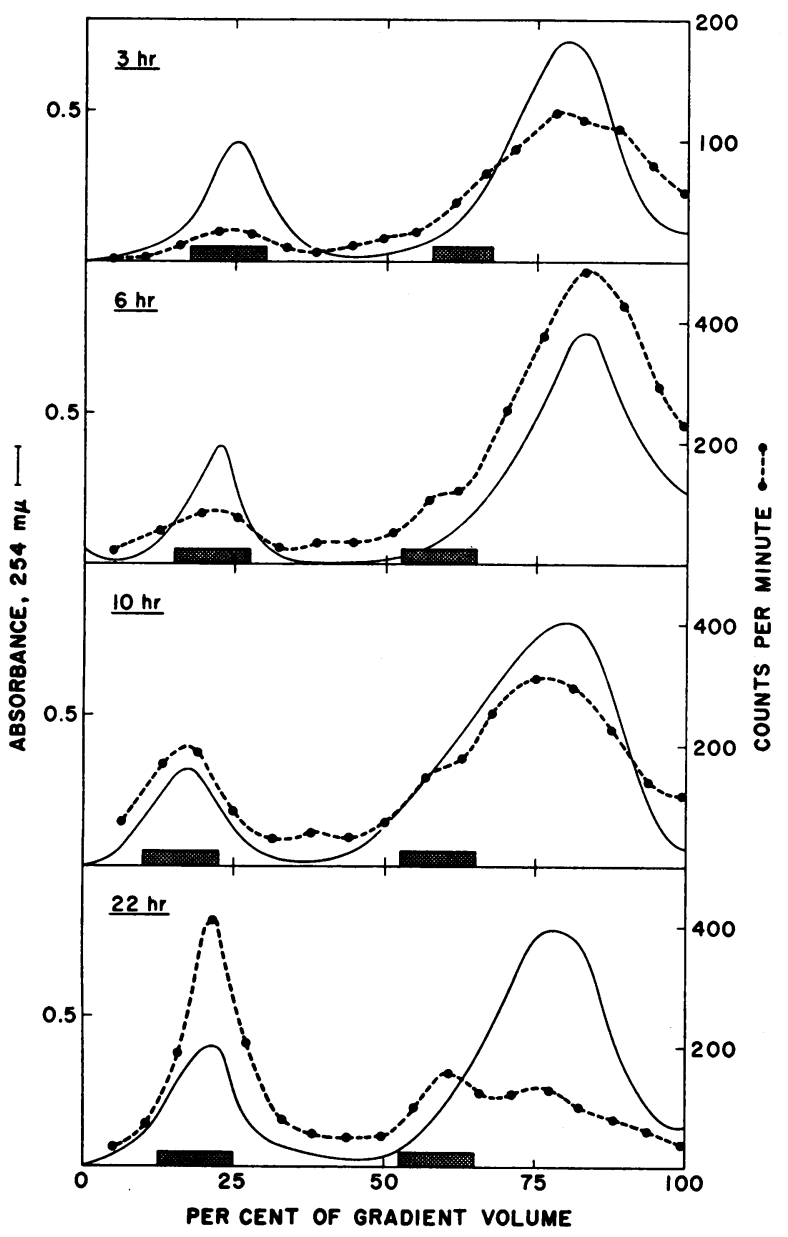

FIGURE 4 The molecular distribution of labeled protein in culture fluids W. F. (1968). Each culture fluid (50 $\mu 1$ of the $3 \mathrm{hr}$ culture fluid and $100 \mu \mathrm{l}$ of the 6,10 , and $22 \mathrm{hr}$ culture fluids) plus $0.2 \mathrm{ml}$ of a $1: 3$ dilution of serum W. F. were layered on a 10-40\% sucrose density gradient and centrifuged (see Methods). The distribution of radioactivity (- - 0 ) in the four culture fluids were compared, and the absorbance profile $(254 \mathrm{~m} \mu)$ of serum protein is indicated by $(|-|)$. The location of labeled protein, determined by radioimmunodiffusion analysis, is indicated by the stippled area.
19S IgM protein was still $4: 1$ as determined by cellulose acetate electrophoretic analysis of the serum; this ratio was reflected in the cultures by the amount of radioactivity associated with each $19 \mathrm{~S}$ protein. The stability of the newly synthesized IgM proteins in a dissociating medium was investigated by comparing the distribution of radioactivity in a culture fluid after centrifugation in a $10-40 \%$ sucrose- $0.15 \mathrm{M} \mathrm{NaCl}$ gradient with the distribution of radioactivity in the culture fluid exposed to $2 \%$ sodium dodecyl sulfate before centrifugation in a gradient containing $0.1 \%$ sodium dodecyl sulfate. The stability of the labeled 19S IgM proteins as well as the labeled 7S IgM protein was evident from the identical profiles of radioactivity obtained from analysis of the densitygradient fractions. The covalent, i.e. disulfide-linked structure of the newly synthesized 19S IgM, was evident from the density-gradient analysis in the presence of a thiol reagent. Centrifugation of culture fluids $\mathrm{F}$. C. and W. F. in $10-40 \%$ sucrose- $0.1 \mathrm{~m}$ Tris- $\mathrm{HCl}, \mathrm{pH} 8.2,0.1$ M 2-mercaptoethanol gradients resulted in the complete disappearance of the rapidly sedimenting protein, with a resultant increase in radioactivity in the midportion of the gradient.

While these studies established the stability of the labeled 19S IgM and 7S IgM to extracellular and certain experimental conditions, it was desired to investigate the stability of $19 \mathrm{~S} \operatorname{IgM}$ to intracellular proteolysis. In May, 1969, a third biosynthetic study was performed in which bone marrow cells from patient W. F. were suspended in the culture medium containing lysine $-{ }^{14} \mathrm{C}$ and isoleucine- ${ }^{14} \mathrm{C}$. The suspension was divided into two equal portions; and after $3 \mathrm{hr}$ of incubation, cycloheximide was added to one tube to yield $100 \mu \mathrm{g} / \mathrm{ml}$ (29). An aliquot of culture fluid was removed immediately, and additional aliquots were removed after 1, 2, and 3 $\mathrm{hr}$ of further incubation. An aliquot was removed from the control tube $1 \mathrm{hr}$ after incubation, and thereafter, at the same time intervals as the cycloheximide-treated (cyclo) cultures. Centrifugation of both control and treated cultures, before the removal of an aliquot of culture fluid, prevented a mechanical decrease in the cell concentration of both cultures. Each culture fluid was analyzed by density-gradient ultracentrifugation and the profile of radioactivity determined. To facilitate the comparisons of radioactivity associated with the $19 \mathrm{~S}$ and $7 \mathrm{~S}$ proteins, we calculated the volume of culture fluid necessary to provide approximately the same total radioactivity for each culture. The radioactivity associated with both the $19 \mathrm{~S}$ and $7 \mathrm{~S}$ proteins was measured, and the per cent of radioactivity associated with each peak was calculated for each culture (Table II). The profiles of radioactivity for the $3 \mathrm{hr}+$ cyclo $(0 \mathrm{hr}), 4 \mathrm{hr}$ + cyclo $(1 \mathrm{hr})$, and $5 \mathrm{hr}+$ cyclo $(2 \mathrm{hr})$ cultures were identical with the profiles of radioactivity for the respec- 
TABLE II

Radioactivity Associated with 195 and $7 S$ Proteins in Control and Cycloheximide-Treated Cultures $W . F$.

\begin{tabular}{|c|c|c|c|c|c|}
\hline \multirow[b]{2}{*}{ Culture } & \multirow[b]{2}{*}{${ }^{14} \mathrm{C}$ total } & \multicolumn{2}{|c|}{${ }^{14} C^{*}$} & \multicolumn{2}{|c|}{$\begin{array}{l}\text { Per cent of } \\
{ }^{14} \mathrm{C}-\text { IgM } \ddagger\end{array}$} \\
\hline & & $19 \mathrm{~S}$ & $7 \mathrm{~S}$ & $19 \mathrm{~S}$ & $7 \mathrm{~S}$ \\
\hline & $c p m$ & $c p m$ & $c p m$ & $\%$ & $\%$ \\
\hline $1 \mathrm{hr}$ control & 6,122 & 220 & 850 & 21 & 79 \\
\hline $3 \mathrm{hr}$ control & 11,998 & 325 & 875 & 27 & 73 \\
\hline $3 \mathrm{hr}+\operatorname{cyclo} \S(0 \mathrm{hr})$ & 11,145 & 370 & 950 & 28 & 72 \\
\hline $4 \mathrm{hr}$ control & 18,269 & 525 & 725 & 42 & 58 \\
\hline $4 \mathrm{hr}+$ cyclo $(1 \mathrm{hr})$ & 17,282 & 525 & 725 & 42 & 58 \\
\hline $5 \mathrm{hr}$ control & 28,141 & 545 & 685 & 44 & 56 \\
\hline $5 \mathrm{hr}+$ cyclo $(2 \mathrm{hr})$ & 26,967 & 600 & 775 & 44 & 56 \\
\hline $6 \mathrm{hr}$ control & 44,807 & 660 & 650 & 50 & 50 \\
\hline $6 \mathrm{hr}+$ cyclo $(3 \mathrm{hr})$ & 36,701 & 625 & 790 & 44 & 56 \\
\hline
\end{tabular}

* The volume of culture fluid analyzed by density-gradient ultracentrifugation was calculated to yield an approximately equivalent number of total counts for each control and each cycloheximide-treated culture.

¥ See footnote 7 .

$\S$ Cyclo = cycloheximide.

tive 3,4 , and $5 \mathrm{hr}$ controls. The distribution of radioactivity for the $1 \mathrm{hr}$ control and the first three cycloheximide-treated cultures is shown in Fig. 5. With both control and cycloheximide-treated cultures the radioactivity associated with $19 \mathrm{~S}$ protein increased with a concomitant decrease in radioactivity associated with $7 \mathrm{~S}$ protein. ${ }^{7}$

Bone marrow cultures $R$. B. were harvested after 3, $6,10,22,28$, and $48 \mathrm{hr}$ of incubation. Radioimmunoelectrophoretic analyses provided evidence for the presence of synthesized IgM in all six culture fluids. The culture fluids were subjected to density-gradient ultracentrifugation, and radioimmunochemical analyses of the gradient fractions revealed the presence of labeled 19S IgM and labeled 7S IgM in the bottom and midportion

\footnotetext{
${ }^{7}$ Confirmation that the radioactivity associated with the $19 \mathrm{~S}$ and $7 \mathrm{~S}$ peaks was attributable to $19 \mathrm{~S} \operatorname{IgM}$ and $7 \mathrm{~S}$ IgM protein was obtained by quantitative precipitin studies on culture fluid W. F. in which specific anti-IgM antiserum and anti-normal human serum (NHS) antiserum were used. Preliminary studies were performed with each antiserum to determine the equivalence point and thereby enable the calculation of the amount of carrier protein necessary to assure optimum precipitation. Isolated 19S IgM and serum W. F. provided carrier protein in the precipitin studies with the anti-IgM antiserum and the anti-NHS antiserum, respectively. Analysis of the supernatant fluid from the antiIgM precipitin study revealed that nonprecipitable $19 \mathrm{~S}$ material represented $1.3 \%$ of the total radioactivity and $7 \mathrm{~S}$ material represented $4 \%$; comparable results were obtained with the anti-NHS antiserum, i.e., $1.3 \%$ and $1.7 \%$ of the total radioactivity were associated with the $19 \mathrm{~S}$ and $7 \mathrm{~S}$ regions, respectively.
}

of the gradient, respectively. Unlabeled $7 \mathrm{~S} \operatorname{IgM}$, isolated from serum W. F., was added to midgradient fractions $\mathbf{R}$. B. before radioimmunodiffusion analysis to provide sufficient carrier protein for precipitin reaction. The radioactivity associated with the $19 \mathrm{~S}$ and $7 \mathrm{~S}$ peaks was determined for each culture, and the per cent of the $19 \mathrm{~S}+7 \mathrm{~S}$ radioactivity was calculated (Table III). A comparison of the profiles of radioactivity revealed a progressive increase in radioactivity associated with the

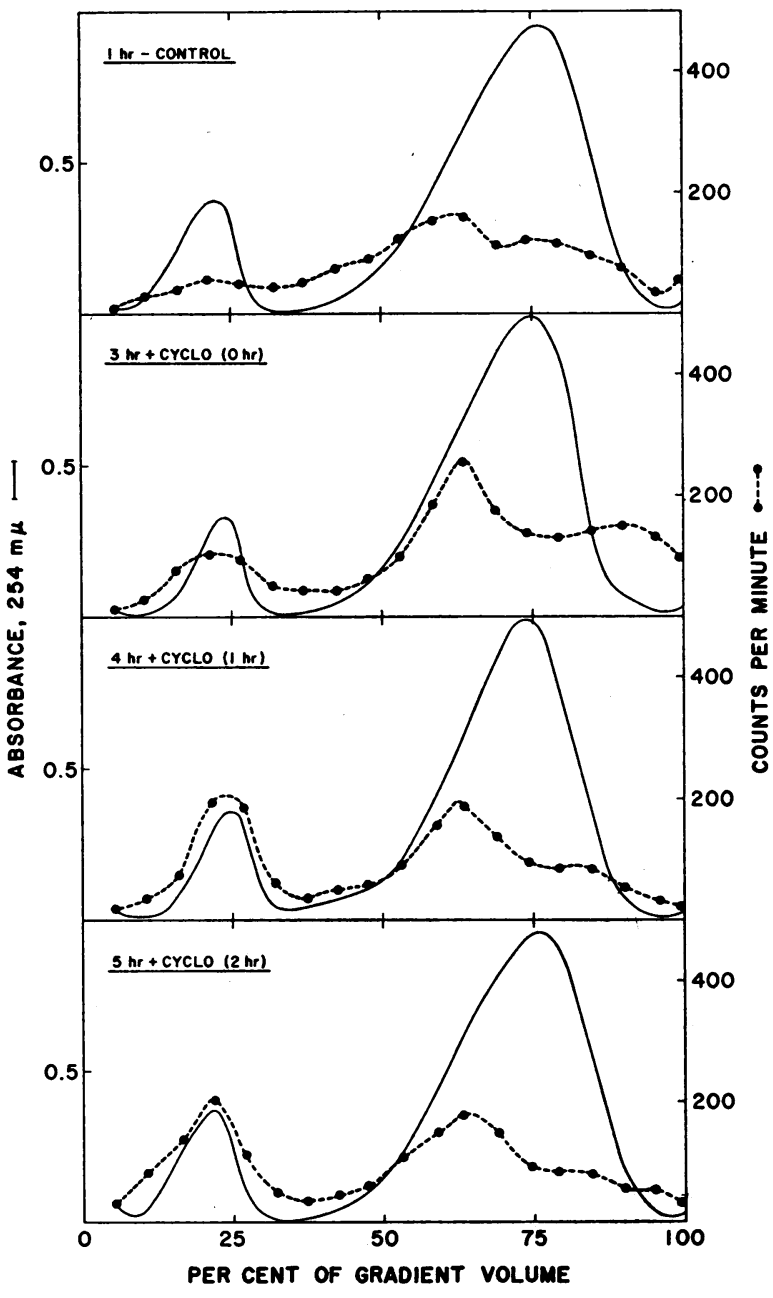

FIGURE 5 The molecular distribution of labeled protein in 1-hr control and cycloheximide-treated cultures W. F. (1969). A volume of culture fluid sufficient to yield an approximately equal total cpm for each culture fluid was added to $50 \mu \mathrm{l}$ of serum W. F. (May, 1969), and was brought to a final volume of $0.4 \mathrm{ml}$ with $0.15 \mathrm{M} \mathrm{NaCl}$. Each sample was centrifuged in a $10-40 \%$ sucrose density gradient (see Methods for details of centrifugation and subsequent analysis). The distribution of radioactivity (---0) and serum protein profile are indicated $(|-|)$. The profiles of radioactivity and protein distribution of the 3,4 , and 5 hr controls (not shown) were identical with the profiles of the respective cycloheximide-treated (cyclo) cultures. 
TABLE III

Radioactivity Associated with $19 S$ and $7 S$ Proteins in Cultures $R$. B.

\begin{tabular}{|c|c|c|c|c|}
\hline \multirow[b]{2}{*}{ Cultures } & \multicolumn{2}{|c|}{${ }^{14} \mathrm{C}$} & \multicolumn{2}{|c|}{$\begin{array}{c}\text { Per cent of } \\
\text { total }{ }^{14} \mathrm{C}-\mathrm{IgM}^{*}\end{array}$} \\
\hline & $19 \mathrm{~S}$ & $7 \mathrm{~S}$ & $19 \mathrm{~S}$ & $7 \mathrm{~S}$ \\
\hline & $c p m$ & $c p m$ & $\%$ & $\%$ \\
\hline $3 \mathrm{hr}$ & 550 & 750 & 42 & 58 \\
\hline $6 \mathrm{hr}$ & 850 & 700 & 55 & 45 \\
\hline $10 \mathrm{hr}$ & 2400 & 1500 & 62 & 38 \\
\hline $22 \mathrm{hr}$ & 3050 & 1300 & 70 & 30 \\
\hline $28 \mathrm{hr}$ & 2500 & 1000 & 71 & 29 \\
\hline $48 \mathrm{hr}$ & 2900 & 1200 & 71 & 29 \\
\hline
\end{tabular}

* See footnote 7 .

19S peak and an accompanying decrease in radioactivity associated with the $7 \mathrm{~S}$ peak in the $3 \mathrm{hr}$ through the 22 $\mathrm{hr}$ cultures. In the 22,28 , and $48 \mathrm{hr}$ cultures the per cent of radioactivity associated with the $19 \mathrm{~S}$ and $7 \mathrm{~S}$ peaks remained constant.

\section{DISCUSSION}

Labeled 7S IgM and 19S IgM were detected in extracellular culture fluids of bone marrow cells from three patients with macroglobulinemia whose sera contained both molecular forms of IgM (see Table I). The labeled $\operatorname{IgM}$ proteins in the culture fluids were identified by radioautography of immunoelectrophoretic and immunodiffusion patterns. The identification of both molecular forms of the IgM in the culture fluids was accomplished by one of two methods. The first method necessitated the physical separation of the $7 \mathrm{~S} \operatorname{IgM}$ and the $19 \mathrm{~S} \operatorname{IgM}$ before radioimmunochemical analyses. The second method required the use of specific carrier protein which made possible the direct radioimmunoelectrophoretic detection of labeled 7S IgM and 19S IgM.

While labeled 7S IgM and 19S IgM were demonstrated in the extracellular culture fluids F. C., W. F., and R. B., the affirmation of the synthetic origin of 7S IgM necessitated the exclusion of the possibility that $7 \mathrm{~S} \mathrm{IgM} \mathrm{is} \mathrm{a}$ degradative or catabolic product of $19 \mathrm{~S}$ IgM by the establishment of the stability of 19S IgM to extracellular and intracellular proteolytic factors. Density-gradient analyses and subsequent determination of the profile of radioactivity of culture fluids which had been repeatedly frozen and thawed revealed a consistency in the profiles with no shift in radioactivity associated with the $19 \mathrm{~S}$ peak to the 7S peak or vice versa. Examination of the profile of radioactivity of a culture fluid, which had been reincubated for twice the original incubation period with bone marrow cells in the medium containing no labeled amino acids, revealed no decrease in radioactivity associated with the $19 \mathrm{~S}$ peak, and thus provided additional evidence for the stability of the labeled 19S IgM protein. The isolation of labeled 19S IgM and subjection of the material to conditions of culture followed by the same processing procedure did not result in breakdown of the $19 \mathrm{~S} \operatorname{IgM}$ as was indicated by the detection of only a single peak of radioactivity confined to the bottom fractions of the density gradient. Both labeled 19S IgM and 7S IgM were stable in the presence of sodium dodecyl sulfate. The disulfide-linked structure of the newly synthesized $19 \mathrm{~S} \operatorname{IgM}$ was evident from centrifugation of a culture fluid containing both labeled $19 \mathrm{~S}$ IgM and $7 \mathrm{~S} \operatorname{IgM}$ in a density gradient containing a thiol reagent.

The stability of $19 \mathrm{~S} \mathrm{IgM} \mathrm{to} \mathrm{in} \mathrm{vivo} \mathrm{catabolic} \mathrm{processes}$ was demonstrated by the lack of formation of labeled 7S IgM upon the injection of isolated radioiodinated $19 \mathrm{~S}$ IgM into the donor patient whose serum contained both 19S IgM and 7S IgM (6). The variation in concentration of $19 \mathrm{~S} \mathrm{IgM} \mathrm{and} \mathrm{7S} \mathrm{IgM} \mathrm{within} \mathrm{an} \mathrm{individual} \mathrm{pa-}$ tient's serum and the lack of a defined relationship between the concentration of $19 \mathrm{~S} \operatorname{IgM}$ and $7 \mathrm{~S} \mathrm{IgM} \mathrm{(Ta-}$ ble $I$, references $7,10,11$ ) imply that $7 \mathrm{~S} \operatorname{IgM}$ is not a breakdown product of 19S IgM. The addition of cycloheximide to a culture system results in the cessation of protein synthesis but does not interfere with the subsequent release of protein present within the cell at the time of the addition (29). If 7S IgM were derived through intracellular proteolysis of $19 \mathrm{~S} \operatorname{IgM}$, then the cessation of protein synthesis in the presence of cycloheximide and the subsequent analysis of culture fluid at timed intervals would presage a decrease in labeled 19S protein with a concomitant increase in labeled 7S protein. Biosynthetic studies to test this prediction did not reveal an increase in radioactivity associated with $7 \mathrm{~S}$ protein, but rather disclosed an increase in radioactivity associated with $19 \mathrm{~S}$ protein. The evidence of the stability of $19 \mathrm{~S}$ IgM to extracellular and intracellular proteolytic factors makes remote the possibility that $7 \mathrm{~S}$ IgM is a degradative or catabolic product of $19 \mathrm{~S} \mathrm{IgM.}$

Although labeled 7S IgM and 19S IgM were demonstrated in the culture fluids of cells from bone marrow, the exact origin of each $\operatorname{IgM}$ protein is not known. The 7S IgM and 19S IgM may arise via either independent synthesis by different cells or within the same cell, $^{8}$ or dependent synthesis in which case the 7S IgM is a precursor of the $19 \mathrm{~S} \mathrm{IgM} \mathrm{or} \mathrm{an} \mathrm{abortive} \mathrm{product} \mathrm{in}$ 19S IgM synthesis. Not only is it speculative as to whether 7S IgM and 19S IgM have an independent or dependent origin, it is not known whether the five

\footnotetext{
${ }^{8}$ Immunofluorescent studies on bone marrow cells from patients with macroglobulinemia have revealed a morphologic diversity in the cells containing IgM (30-32). Immunofluorescent studies with antisera that can distinguish between $7 \mathrm{~S} \operatorname{IgM}$ and 19S IgM should provide evidence on the single or separate origin of the two molecular forms of IgM.
} 
monomeric subunits of the $19 \mathrm{~S} \operatorname{IgM}$ form the pentameric association intracellularly or extracellularly. Comparisons of the distribution of radioactivity associated with the 7S IgM and $19 \mathrm{~S} \operatorname{IgM}$ in consecutive timed culture fluids (W. F. and R. B.) show that the radioactivity associated with $7 \mathrm{~S}$ IgM progressively decreased with a concomitant increase in radioactivity associated with 19S IgM, and thus suggest a precursorproduct relationship between $7 \mathrm{~S}$ IgM and 19S IgM. While the radioactivity associated with the top (most slowly sedimenting) peak obtained by density-gradient analyses of the cultures decreased as the radioactivity associated with the 19S IgM increased, no $\mu$ heavy chain determinants were detected in the labeled material in this peak; and the significance of this material is under investigation.

The presence of the two distinct 19S IgM proteins as well as $7 \mathrm{~S} \mathrm{IgM} \mathrm{in} \mathrm{the} \mathrm{serum} \mathrm{W.} \mathrm{F.} \mathrm{was} \mathrm{a} \mathrm{remarkable}$ and rare occurrence. The three proteins differed in electrophoretic mobility and in individual solubility properties. The less cathodal 19S IgM was a euglobulin, and the three $\operatorname{IgM}$ proteins differed in their susceptibility to precipitation by ammonium sulfate. Antiheterologous IgM antisera did not distinguish between the 7S IgM and 19S IgM proteins W. F., however, current studies with antisera prepared against each isolated protein W. F. reveal antigenic differences among the three IgM proteins. Studies on both isolated 19S IgM proteins W. F. yielded no evidence of breakdown to $7 \mathrm{~S} \operatorname{IgM}$ as a result of freezing-thawing, prolonged dialysis, or lyophilization. Although the concentration of the total 19S IgM at the time of the April, 1968 , studies was twice the concentration at the time of the May, 1969, studies, the ratio between the two 19S IgM proteins had remained constant as was evidenced by serum and culture analyses which revealed that the ratio of the radioactivity associated with the two synthesized 19S IgM proteins was consistent with the ratio of the concentration of the two 19S IgM proteins in the serum W. F.

The presence of $19 \mathrm{~S} \operatorname{IgM}$ and $7 \mathrm{~S} \mathrm{IgM} \mathrm{in} \mathrm{human} \mathrm{sera}$ bears close correspondence to the presence of $19 \mathrm{~S}$ and $7 \mathrm{~S}$ components in the serum of certain primitive species. Studies on the phylogenetic development of immuno-

\footnotetext{
${ }^{\theta}$ It has been postulated (9) that the presence of naturally occurring 7S $\operatorname{IgM}$ is a result of an absence or blockage of the cysteinyl residue at the carboxyl-terminus of the $\mu$ heavy chain, thus preventing polymerization. In the process of purifying by gel filtration under alkaline conditions a preparation of $7 \mathrm{~S}$ IgM which contained no contaminating 19S IgM, we noted that a portion of the naturally occurring 7S IgM had undergone spontaneous polymerization to a $19 \mathrm{~S}$ polymer. This polymer was dissociated by mercaptans to 7S IgM; however, the site of interchain disulfide linkage has not been determined.
}

globulin structure and function have shown that certain species of lower vertebrates synthesize only one class of immunoglobulins (33-35). This immune system consists of two antigenically related $19 \mathrm{~S}$ and $7 \mathrm{~S}$ components. Physicochemical and structural analyses have revealed marked similarity between the $19 \mathrm{~S}$ and $7 \mathrm{~S}$ immunoglobulins of lower vertebrates and immunoglobulin $\mathbf{M}$ of higher vertebrates (36). The presence of synthesized $7 \mathrm{~S}$ and 19S immunoglobulins in lower vertebrates and the apparent synthetic origin of 7S IgM and 19S IgM in man supports the concept that ontogenesis recapitulates phylogenesis and suggests that the 7S IgM in man may represent an atavistic immune response.

\section{ACKNOWLEDGMENTS}

We express our appreciation to Doctors N. Granville and J. L. Fahey for permission to study patient F. C., to Doctors F. H. Payne and J. C. Hathaway for referral of patient W. F., and Doctors C. L. Neely, A. P. Kraus, and R. Walker for permission to study patient R. B.

This investigation was supported by research grants from the American Cancer Society (T-420), the National Science Foundation (GB 6036), and the National Cancer Institute (CA-10056-04). Dr. Solomon is the Recipient of Research Career Development Award 5-K3-CA-21, 229 from the National Cancer Institute.

\section{REFERENCES}

1. Solomon, A., and C. L. McLaughlin. 1967. Molecular polymorphism of $\gamma \mathrm{M}$-globulin: in vitro and in vivo studies. Blood. 30: 871. (Abstr.)

2. Kunkel, H. G. 1960. Macroglobulins and high molecular weight antibodies. In The Plasma Proteins. F. W. Putnam, editor. Academic Press Inc., New York. 1: 279.

3. Killander, J. 1963. Separation of human immunoglobulins by gel filtration and zone electrophoresis. Acta Soc. Med. Upsal. 68: 230.

4. Rothfield, N. F., B. Frangione, and E. C. Franklin. 1965. Slowly sedimenting mercaptoethanol-resistant antinuclear factors related anti-genically to $M$ immunoglobulins $\left(\gamma_{1 M}-\right.$ globulin) in patients with systemic lupus erythematosus. J. Clin. Invest. 44: 62 .

5. Gleich, G. J., J. W. Uhr, J. H. Vaughan, and H. A. Swedlund. 1966. Antibody formation in dysgammaglobulinemia. J. Clin. Invest. 45: 1334.

6. Solomon, A., and H. G. Kunkel. 1967. A "monoclonal" type, low molecular weight protein related to $\gamma \mathrm{M}$ macroglobulins. Amer. J. Med. 42: 958.

7. Stobo, J. D., and T. B. Tomasi, Jr. 1967. A low molecular weight immunoglobulin antigenically related to $19 \mathrm{~S}$ IgM. J. Clin. Invest. 46: 1329.

8. Klein, F., P. Mattern, H. Radema, and T. L. Van Zwet. 1967. Slowly sedimenting serum components reacting with anti-IgM sera. Immunology. 13: 641.

9. Perchalski, J. E., L. W. Clem, and P. A. Small, Jr. 1968. 7S gamma-M immunoglobulins in normal human cord serum. Amer. J. Med. Sci. 256: 107.

10. Solomon, A. 1969. Molecular heterogeneity of immunoglobulin-M ( $\gamma \mathrm{M}$-globulin). J. Immunol. 102: 496.

11. Bush, S. T., H. A. Swedlund, and G. J. Gleich. 1969. Low molecular weight IgM in human sera. J. Lab. Clin. Med. 73: 194. 
12. Swedlund, H. A., G. J. Gleich, and W. B. Chodirker. 1968. Comparison of certain properties of naturally occurring low molecular weight $\gamma \mathrm{M}$ and the $\gamma \mathrm{M}$ monomer derived by reduction and alkylation of $19 \mathrm{~S} \gamma \mathrm{M}$. J. Immunol. 100: 1296.

13. Deutsch, H. F., and J. I. Morton. 1957. Dissociation of human serum macroglobulins. Science (Washington). 125: 600 .

14. Miller, F., and H. Metzger. 1965. Characterization of a human macroglobulin. I. The molecular weight of its subunit. J. Biol. Chem. 240: 3325.

15. Morris, J. E., and F. P. Inman. 1968. Isolation of the monomeric subunit of immunoglobulin $M$ with its interchain disulfide bonds intact. Biochemistry. 7: 2851.

16. Doolittle, R. F., and S. J. Singer. 1966. Evolution of immunoglobulin polypeptide chains: carboxy-terminal of an IgM heavy chain. Science (Washington). 154: 1561.

17. Abel, C. A., and H. M. Grey. 1967. Carboxy-terminal amino acids of $\gamma \mathrm{A}$ and $\gamma \mathrm{M}$ heavy chains. Science (Washington). 156: 1609.

18. Suzuki, T., and H. F. Deutsch. 1967. Dissociation, reaggregation, and subunit structure studies of some human rM-globulins. J. Biol. Chem. 242: 2725.

19. Lowry, O. H., N. J. Rosebrough, A. L. Farr, and R. J. Randall. 1951. Protein measurement with the Folin phenol reagent. J. Biol. Chem. 193: 265.

20. Schachman, H. K. 1959. Ultracentrifugation in Biochemistry. Academic Press Inc., New York.

21. Kunkel, H. G. 1954. Zone electrophoresis. Methods Biochem. Anal. 1: 141.

22. Scheidegger, J. J. 1955. Une micro méthode de l'immuno électrophorèse. Int. Arch. Allergy Appl. Immunol. $7: 103$.

23. Ouchterlony, O. 1958. Diffusion in gel methods for immunological analysis. Progr. Allergy. 5: 1.

24. Fahey, J. L., and C. McLaughlin. 1963. Preparation of antisera specific for $6.6 \mathrm{~S} \gamma$-globulins, $\beta_{2 \Delta}$-globulins, $\gamma_{1-}$ macroglobulins and for type I and II common $\gamma$-globulin determinants. J. Immunol. 91 : 484.

25. Merrill, D., T. F. Hartley, and H. N. Claman. 1967. Electroimmunodiffusion (EID) : a simple, rapid method for quantitation of immunoglobulins in dilute biological fluids. J. Lab. Clin. Med. 69: 151.

26. Fleischman, J. B., R. H. Pain, and R. R. Porter. 1962. Reduction of $\gamma$-globulins. Arch. Biochem. Biophys. (Suppl. 1) : 174.

27. Hochwald, G. M., G. J. Thorbecke, and R. Asofsky. 1961. Sites of formation of immune globulins and of a component of $\mathrm{C}_{3}^{\prime}$. I. A new technique for the demonstration of the synthesis of individual serum proteins by tissues in vitro. J. Exp. Med. 114: 459.

28. Bray, G. A. 1960. A simple efficient liquid scintillator for counting aqueous solutions in a liquid scintillation counter. Anal. Biochem. 1: 279.

29. Wettstein, F. O., H. Noll, and S. Penman. 1964. Effect of cycloheximide on ribosomal aggregates engaged in proteins synthesis in vitro. Biochim. Biophys. Acta. $87: 525$.

30. Zucker-Franklin, D., E. C. Franklin, and N. S. Cooper. 1962. Production of macroglobulins in vitro and a study of their cellular origin. Blood. 20: 56 .

31. Solomon, A., J. L. Fahey, and R. A. Malmgren. 1963. Immunohistologic localization of gamma-1-macroglobulins, beta-2A-myeloma proteins, 6.6 $\mathrm{S}$ gamma-myeloma proteins and Bence Jones proteins. Blood. 21: 403.

32. Van Furth, R., H. R. E. Schuit, and W. Hijmans. 1966. The formation in vitro of paraproteins in multiple myeloma and Waldenström's macroglobulinaemia. Brit. J. Haematol. 12: 202.

33. Marchalonis, J., and G. M. Edelman. 1965. Phylogenetic origins of antibody structure. I. Multichain structure of immunoglobulins in the smooth dogfish (Mustelus canis). J. Exp. Med. 122: 601 .

34. Clem, L. W., and P. A. Small, Jr. 1967. Phylogeny of immunoglobulin structure and function. I. Immunoglobulins of the lemon shark. J. Exp Med. 125: 893.

35. Clem, L. W., F. DeBoutaud, and M. M. Sigel. 1967. Phylogeny of immunoglobulin structure and function. II. Immunoglobulins of the nurse shark. J. Immunol. 99: 1226.

36. Marchalonis, J., and G. M. Edelman. 1966. Polypeptide chains of immunoglobulins from the smooth dogfish (Mustelus canis). Science (Washington). 154: 1567. 